\title{
FACTORS ASSOCIATED WITH FALCIPARUM MALARIA IN LEMBATA, EAST NUSA TENGGARA
}

\author{
Rafael Paun \\ School of Health Polytechnics, Ministry of Health, Kupang
}

\begin{abstract}
Background: Lembata district, East Nusa Tenggara, is a malaria endemic area. In 2016, as many as 27,976 clinical suspect cases were reported. As many as 6,562 malaria cases were confirmed, of which 444 were Plasmodium falciparum cases, 6,116 were Plasmodium vivax cases, and 2 mixed cases. Annual Parasite Incidence (API) was 46.60 new cases per thousand populations. This study aimed to determine the factors associated with Falciparum malaria in Lembata, East Nusa Tenggara.

Subjects and Method: This was a case control study carried out in Lembata, East Nusa Tenggara. A sample of 226 people was selected for this study, consisting of 113 Falciparum malaria cases and 113 controls. The dependent variable was Falciparum malaria. The independent variables were age, fever, convulsion, and diarrhea. Malaria case was diagnosed by anamnesis, clinical and laboratory examinations. The other data were collected by questionnaire, interview, and observation. The data were analyzed by a multiple logistic regression.

Results: Falciparum malaria was associated with younger age $(\mathrm{OR}=2.88$; $95 \%$ $\mathrm{CI}=1.47$ to $5.07 ; \mathrm{p}<0.001)$, high fever $(\mathrm{OR}=5.88 ; 95 \% \mathrm{CI}=4.21$ to $7.45 ; \mathrm{p}=0.001)$, convulsion $(\mathrm{OR}=4.90 ; 95 \% \mathrm{CI}=2.09$ to $7.63 ; \mathrm{p}<0.001)$, and diarrhea $(\mathrm{OR}=3.76$; $95 \% \mathrm{CI}=1.16$ to $8.75 ; \mathrm{p}=0.023$ ).
\end{abstract}

Conclusion: Falciparum malaria is associated with younger age, high fever, convulsion, and diarrhea.

Keywords: malaria, Falciparum, fever, convulsion, diarrhea

\section{Correspondence:}

Rafael Paun. School of Health Polytechnics, Ministry of Health, Kupang, Jl. Piet A. Tallo, Kupang, East Nusa Tenggara. Email: rafpuno12@gmail.com.

Mobile: 081339334949 